Article

\title{
Biochar Application in Malaysian Sandy and Acid Sulfate Soils: Soil Amelioration Effects and Improved Crop Production over Two Cropping Seasons
}

\author{
Theeba Manickam ${ }^{1}$, Gerard Cornelissen ${ }^{2,3,4}$, Robert T. Bachmann ${ }^{5}$, Illani Z. Ibrahim ${ }^{1}$, \\ Jan Mulder ${ }^{3}$ and Sarah E. Hale ${ }^{2, *}$
}

Received: 23 October 2015; Accepted: 15 December 2015; Published: 18 December 2015

Academic Editor: Zhiyong Jason Ren

1 Crop and Soil Science Research Center, Malaysia Agriculture Research and Development Institute

Malaysia (MARDI), Jalan Persiaran MARDI-UPM, 43000 Selangor, Malaysia; theeba@mardi.gov.my (T.M.); iiani@mardi.gov.my (I.Z.I.)

2 Department of Environmental Engineering, Norwegian Geotechnical Institute (NGI), P.O. Box 3930 Ullevål Stadion, N-0806 Oslo, Norway; gco@ngi.no

3 Institute for Plant and Environmental Sciences (NMBU), Norwegian University of Life Sciences, 5003 Ås, Norway; jan.mulder@nmbu.no

4 Department of Applied Environmental Sciences (ITM), Stockholm University, 10691 Stockholm, Sweden

5 Universiti Kuala Lumpur, Malaysian Institute of Chemical and Bioengineering Technology (UNIKL-MICET), 78000 Alor Gajah, Melaka, Malaysia; bachmann@micet.unikl.edu.my

* Correspondence: sah@ngi.no or sarah.hale@ngi.no; Tel.: +47-4694-8357

\begin{abstract}
The use of biochar as an agricultural soil improvement was tested in acid sulfate and sandy soils from Malaysia, cropped with rice and corn. Malaysia has an abundance of waste rice husks that could be used to produce biochar. Rice husk biochar was produced in a gasifier at a local mill in Kelantan as well as in the laboratory using a controlled, specially designed, top lift up draft system (Belonio unit). Rice husk biochar was applied once to both soils at two doses ( $2 \%$ and $5 \%$ ), in a pot set up that was carried out for two cropping seasons. Positive and significant crop yield effects were observed for both soils, biochars and crops. The yield effects varied with biochar type and dosage, with soil type and over the cropping seasons. The yield increases observed for the sandy soil were tentatively attributed to significant increases in plant-available water contents (from $4 \%-5 \%$ to $7 \%-8 \%$ ). The yield effects in the acid sulfate soil were likely a consequence of a combination of (i) alleviation of plant root stress by aluminum $(\mathrm{Ca} / \mathrm{Al}$ molar ratios significantly increased, from around 1 to 3-5) and (ii) increases in CEC. The agricultural benefits of rice husk biochar application to Malaysian soils holds promise for its future use.
\end{abstract}

Keywords: biochar; rice husk; Malaysia; acid sulfate; pot trial; multiple seasons; corn; rice

\section{Introduction}

Biochar is produced by pyrolyzing biomass, ideally from organic waste products which have no further commercial purpose, into stable biochars. This process removes carbon from the short term carbon cycle [1]. In Asia, rice husks are a waste material of abundant quantity that could provide a biomass source for the production of biochar. Indeed, in 2011, an estimated 592,477 tons of rice husk and 32,000 tons of rice husk biochar were generated from rice milling operations in Malaysia [2] In large rice processing mills in Malaysia, fresh rice husks generated as a byproduct of the process are utilized as fuel. They are gasified using cyclone furnaces to generate heat for the rice drying process and the rice husk biochar produced (at a recovery rate of approximately $30 \%$ ) is predominantly considered as a waste byproduct. Rice drying is a batch process and is carried out over a period 
of three months per year during each paddy harvest period. Rice husk biochar has been used in agricultural practices since the beginning of rice cultivation in Asia several thousands of years ago. In the state of Kedah (in the northern area of Peninsular Malaysia), rice husk biochars produced by rice mills are utilized as a seedling bed for the rice transplanting technique practiced in that state. In Kedah farmers are able to acquire the rice husk biochar free of charge. However, in other areas of Malaysia such as Kelantan (on the east coast of Peninsular Malaysia), rice husk biochar is considered a problematic waste material and mill owners pay approximately 1 USD to dispose of 3.38 tons of the material due to ineffective utilization. A small proportion of farmers in Kelantan have recently started utilizing rice husk biochar as a potting media for vegetables under fertigation systems, replacing commonly used cocoa peats.

Amending biochar to soil is being promoted as a sustainable practice that simultaneously mitigates climate change and improves the quality of marginalized agricultural land in impoverished regions. The amendment of small doses of biochar to soils in such regions has been carried out in many continents (summarized in [1]). Biochar amendment to soil can result in an increase in $\mathrm{pH}$, increase in cation exchange capacity (CEC) [3], improved water holding capacity, and improved soil structure [4]. Amendment studies have demonstrated both positive and negative results following biochar addition. A meta-analysis of 16 biochar studies considering 177 different treatments showed that the effect of biochar on crop yield is variable, ranging from $-28 \%$ to $+39 \%$, with an overall mean of $+10 \%$ [5]. The study cited plant-available water, $\mathrm{pH}$ and nutrient retention increases as the most important factors explaining the effect of biochar addition on plant growth. However, in many studies it was not completely clear what factor was decisive for the observed biochar effects, or lack thereof, on crop yield. In addition, a further meta-analysis was carried out in order to investigate the effect of biochar amendment on crop growth both for pot and field experiments [6]. These authors found that when the biochar dose was $<30 \mathrm{t} / \mathrm{ha}$, crop productivity was increased by $11 \%$ on average, with greater responses found in pot experiments than in field experiments, in acidic soils compared to neutral soils, and in sandy soils compared to loamy and silty soils.

Malaysian soils can be broadly divided into the sedentary soils formed in the interior areas of Malaysia on a wide variety of rock types, and soils that are found in the coastal alluvial plains. The coastal alluvial soils can be classified as Entisols, Histosols, Inceptisols, and Spodosols and fall in to four main categories; fine textured clay soils, peat and organic soils, acid sulfate soils and sandy soils [7]. It is often the acid sulfate soils and the sandy soils that are most problematic from an agricultural perspective. Acid sulfate soils occur almost exclusively in the coastal plains of Malaysia [8,9]. These soils are characterized by high levels of pyrite $\left(\mathrm{FeS}_{2}\right)$ which produce high acidity (soil $\mathrm{pH}<4$ ) when they are exposed to the atmosphere due to drainage, resulting in the release of high amounts of $\mathrm{Al}^{3+}$ and $\mathrm{Fe}^{2+}$ into the environment [10]. The sandy spodosols (>85\% sand) are considered problematic due to excessive water drainage as well as low organic matter contents, clay contents, cation exchange capacities (CEC) and nutrient contents. Water and nutrients are easily leached out of the soil due to the low field capacity and the low CEC respectively, and thus water and nutrient stress are common.

Reported studies probing the effects of the addition of biochar to Malaysian soils are scarce. However, Malaysian universities and research agencies (personal communications) have carried out several unpublished studies. Of those that have been published, the use of biochar has been shown to be one possible way to ameliorate poor agricultural soils. For example, the addition of $4 \% \mathrm{wt}$ of rice husk biochar to compost accelerated the composting process as the rice husk biochar acted as a bulking agent and promoted higher decomposition rates due to a larger microbial population being present at the thermophilic stage, as well as higher moisture and nutrient retention [2]. Panhwar et al. [11] studied the effects of biochar and organic matter amendments on rice grown on acid sulfate soil from Kelantan. The application of $4 \mathrm{t} /$ ha biochar in combination with $9 \mathrm{t} /$ ha biofertilizer resulted in a significant increase in soil $\mathrm{pH}$ and crop yield as compared to the control, non-amended soil. Syuhada et al. [12] studied the effects of biochar amendment on nutrient uptake of corn planted under sandy Malaysian spodosols. The results showed that the addition of biochar at $20 \mathrm{t} / \mathrm{ha}$ in combination 
with fertilizer significantly increased the uptake of nitrogen by corn compared to the control. However, when applying biochar to soil as an amendment with the aim to improve the agronomic quality of the soil, the effect of co-formed polycyclic aromatic hydrocarbons (PAHs) and potentially toxic elements (PTEs) must also be considered. Previous research has shown that the level of PAHs in a broad suite of biochars produced using different methods and from different feedstocks does not result in biochars containing total PAH concentrations or bioavailable PAH concentrations above guideline values set by relevant biochar standards [13]. Specifically for biochars produced form rice husk, previous studies have also reported low concentration of PTEs [14] that do not exceed guideline values set by the UK for the use of sewage sludge application to soil [15]. One additional environmental issue specifically related to the addition of rice husk biochar to soil is the high amount of silicates in the biomass which may lead to the production of crisobalite, an element with associated health concerns, during the gasification process [15].

Previous biochar trials have been carried out for similar problematic soils to those in Malaysia, in other countries. The application of rice husk biochar together with mineral fertilizers and lime significantly enhance the root nodule formation, growth and yield of maize in Indonesia [16]. In Thailand, Oka [17] reported the positive effects of $10 \mathrm{t} /$ ha rice husk biochar application on nitrogen fixation rates, growth and yield of soy bean planted in a low fertile sandy soil. The authors explained the positive effects based on an improvement of soil physical properties, porosity, water holding capacity, $\mathrm{pH}$ and CEC resulting from the amendment of biochar. Jaafar et al. [18] studied the response of arbuscular mycorrhizal towards biochar soil amendment and reported that application of $50 \mathrm{t} / \mathrm{ha}$ of biochar gave significantly higher colonization of mycorrhizal root for subterranean clover and wheat. Kameyama et al. [19] reported that the addition of 1\%-10\% wt sugarcane bagasse biochar produced at $800{ }^{\circ} \mathrm{C}$ to two types of sandy soils in Japan increased the water retention capacity of the soils proportionally to the amount of biochar added. Steiner et al. [20] reported charcoal from secondary forest wood addition to compost at $5 \mathrm{t} / \mathrm{ha}$ and $11 \mathrm{t} / \mathrm{ha}$, respectively, gave higher stover and grain yield compared to mineral fertilization alone and its presence in the soil was as measured by carbon loss, was more stable compared to other organic amendments such as chicken manure and compost.

Within this study, the amelioration effects of adding rice husk biochar to two problematic soils from Kelantan, namely sandy spodosols and acid sulfate soils over two cropping season was investigated in greenhouse pot trials. The rice husk biochar was applied just once and residual effects resulting from the application were evaluated in a second cropping cycle. Rice husk biochars were produced locally in two manners: (i) in a rice mill using a cyclone gasifier and a gasification process (the above mentioned waste product) and (ii) in a controlled manner using an upscaled Belonio device [21]. Corn (Zea mays) and rice (Oryza sativa) were selected as test crops as they are currently grown under sandy spodosols and acid sulfate soils but often have a low average yield. The working hypothesis was that these biochars could increase crop yields in these soils by favorable changes in soil physico-chemical properties, specifically water stress relief in the sandy soil and acid stress relief in the acid sulfate soil. This study extends knowledge related to the use of biochar as a soil amendment to Malaysian soils by considering two biochars applied at two rates to two problematic soils planted with two types of crop over two cropping seasons. The study is among the first to probe the possible use of gasifier rice husk biochar in Malaysia, a readily and cheaply available biomass waste material from rice mills that promotes positive waste management strategies.

\section{Experimental Section}

\subsection{Selection of Rice Husk Biochar}

Rice husk biochar was produced using two different methods: (1) available rice husk biochar produced at a local mill (BERNAS mill at Peringat in Kelantan) via gasification, referred to as R (rice mill biochar) and (2) upscaled top-lit updraft Belonio rice husk gasifier [21], referred to as B (biochar belonio). The selection of rice husk as a feedstock was based on predicted long term availability of 
the material since rice is a staple food in Malaysia and rice husk biochar is an abundantly available byproduct of existing gasification units, which are used in major rice processing mills. Figure S1 in the Supplementary Materials provides a schematic of the system at the rice mill. The cyclonic furnace consists of a combustion chamber, feeding system of air and rice husk, a suction blower and a control system. During the gasification process, rice husk is fed into the furnace through a husk inlet until it reaches the height required. Start-up of the cyclonic furnace is carried out with the aid of burning diesel. The burning temperature in the combustion chamber is set to $350^{\circ} \mathrm{C}$ although the temperature inside the cyclonic furnace can briefly reach temperatures up to $1000{ }^{\circ} \mathrm{C}$. The furnace operates by blowing the rice husk from a husk bin into the top of the furnace. Through the double cyclone, rice husk is swirled around and mixed with air that is injected at six different heights into the furnace. Combustion takes place within the whole height of the furnace. The rice husk biochar is collected at the bottom of the furnace. The hot combustion gasses are fed from the top of the furnace into the dryer, where it is mixed with ambient air through a second blower.

The upscaled top-lit updraft Belonio rice husk gasifier was developed in the present research project and operated under controlled conditions as described by Kisiki et al. [21]. In brief, $70 \mathrm{~kg}$ of rice husk were added to the Belonio gasifier which were lit with the aid of paper. Once the rice husk caught fire the lid was closed and air supplied via a centrifugal blower until the gasification zone reached the bottom of the unit, typically within 2.5 to $3 \mathrm{~h}$. Following this the blower was turned off and biochar removed and left to cool. The average biochar yield was $21.3 \mathrm{~kg} \pm 4.6 \mathrm{~kg}(15 \%)$, while peak temperatures increased from 600 to $830^{\circ} \mathrm{C}$ (as measured by digital thermocouples mounted in the unit) as the gasification zone moved downwards.

\subsection{Selection of Soils}

The soils from Kelantan that were selected for the experiments were (a) an acid sulfate soil and (b) a sandy soil. The acid sulfate soil was collected form Kampong Golok, Kemasin Semerak $\left(6^{\circ} 3^{\prime} 5^{\prime \prime} \mathrm{N}\right.$, $102^{\circ} 16^{\prime} 47^{\prime \prime}$ E), which is an area where paddy rice has been cultivation for more than five years with governmental subsidized liming application. The sandy spodosol soil was collected form the Malaysian Agricultural Research and Development Institute (MARDI) research station in Telong, Bachok and is an area which is currently cultivated with sweet potato and maize (corn). The average yearly rainfall is $3000 \mathrm{~mm}$ and the average temperature $32{ }^{\circ} \mathrm{C}$ at both sites. Soil was sampled at a depth of $20 \mathrm{~cm}$.

\subsection{Characterizations of Rice Husk Biochar and Soil}

The selected rice husk biochar and soils were characterized using standard procedures and all analyses were carried out in triplicate. Bulk density of both rice husk biochar and soils were determined using a core method after Blake and Hartge (1986). The ash content of rice husk biochar was determined in accordance to a standard thermogravimetric procedure by heating to $550{ }^{\circ} \mathrm{C}$ to obtain the ash fraction of the biochar. Samples of rice husk biochar were air dried, crushed and sieved through a $0.15-\mathrm{mm}$ sieve before being characterized. Soil samples were air-dried and sieved to pass through a $2 \mathrm{~mm}$ sieve prior to analysis. The $\mathrm{pH}$, total carbon, CEC and water retention capacity of both rice husk biochar and soil were determined. The $\mathrm{pH}$ was measured in water using a $\mathrm{pH}$ meter (Mettler Toledo, Delta 320) at a sample:water ratio of 1:5 $w / v$. Total carbon was measured by element analysis using a Perkin Elmer 2400 Series II CHNOS Analyzer. CEC was analyzed using a double leaching method at $\mathrm{pH} 7$ with ammonium acetate [22] and exchangeable bases were quantified using an Inductive Couple Plasma analysis of the first leachate with $1 \mathrm{~N} \mathrm{NH}_{4} \mathrm{OAc}$. Water retention capacity was determined using a pressure plate and a pressure membrane method. This method involves a series of equilibria between water in the sample and body of water at known potential ( $\mathrm{pF}$ curves). The water retained at $\mathrm{pF} 2$ was defined as field capacity, the water retained at $\mathrm{pF} 4.2$ as permanent wilting point, and the difference between the two as the plant-available water. The acid neutralizing capacity of rice husk biochar (also referred to as alkalinity) was determined from a back titration method using $0.01 \mathrm{M} \mathrm{NaOH}$. The soil microbial population was determined using a serial dilution 
technique where $10 \mathrm{~g}$ soil was diluted in $90 \mathrm{~mL}$ of sterilized saline water. After the series of dilution steps, the incubated media agar plates were visualized for colony growth, counted and the microbial population calculated in total colony forming units (cfu-log 10$)$.

\subsection{Pot Trial}

The pot trial was carried out under a rain shelter at the MARDI research station in Kubang Keranji using a completely randomized design (Supplementary Materials Figure S2). Two soils, acid sulfate soil and sandy soil; two crops, corn (Zea mays) and rice (Oryza sativa); two rice husk biochars, locally produced mill biochar $(\mathrm{R})$ and belonio produced biochar (B); both applied at two doses, $2 \%$ and $5 \% \mathrm{wt}$; and over two cropping seasons were tested. The biochar doses were added based on the dry weight of the soil. Rice was only grown under acid sulfate soil and overall the experimental design consisted of 60 pots. Standard fertilizer rates and crop establishment techniques were practiced for all of the treatments and details of these are shown in Table S1 in the Supplementary Materials. In brief, fertilizer was added to the pots for the rice after 12, 25, 45 and 65 days of growth and for the corn after 15, 25 and 46 days. The doses varied between $0.716 \mathrm{~g}$ per pot up to $7.50 \mathrm{~g}$ per pot for the NPK mixture according to soil, crop and time of amendment. In addition urea was added to the pots at doses of $0.716 \mathrm{~g}$ per pot for the rice cropped on acid sulfate soil and $5.63 \mathrm{~g}$ per pot for the soils cropped with corn. A control treatment without rice husk biochar amendment was used as comparison. Treatments are referred to as Control (C), Belonio rice husk biochar amended at 2\% (B2), Belonio rice husk biochar amended at $5 \%$ (B5), mill rice husk biochar amended at 2\% (R2), and mill rice husk biochar amended at 5\% (R5) throughout. All pot experiments were carried out in four replicates per treatment.

Rice husk biochars were mixed into the topsoil layer during the pot preparation as illustrated in the schematic in Figure S3 in the Supplementary Materials. Owing to the excessive drainage problem that occurs in Malaysian sandy soils, the pots were designed to have a leachate chamber at the bottom to collect the leachate water and to allow the water retention capacity resulting from the application of biochar to be measured (Figure S4 in the Supplementary Materials). The leachate from the pots containing sandy soil was collected throughout the cropping cycle and the volume was measured. As the pot trials were carried out under a rain shelter, corn was irrigated with tap water as $450 \mathrm{~mL} /$ pot/day for sandy soil and $300 \mathrm{~mL} /$ pot/day for acid sulfate soil. Rice was planted under flooded conditions and the minimal amounts of water needed to maintain a water depth of $5 \mathrm{~cm}$ in the pot (200 mL per pot/day) were supplied. Figure S5 in the Supplementary Materials provides photographs of the pot trial.

The pot trial was carried out for two cropping seasons, 75 days per season for corn and 95 days per season for rice, without the re-application of biochar between seasons. After harvesting the crops following the first growth season, the pots were reused for the second season and new crops were directly planted. The same amount of fertilizer as detailed above was re-added to the pots. Physico-chemical analysis of the soil plus biochar was carried out at the end of both the first and the second cropping season. In addition, the crop yield of rice was determined by measuring the weight of the grain on a tons per hectare basis. The yield of corn was determined as the weight of the fresh $\mathrm{cob}$ in tons per hectare.

\subsection{Statistical Analysis}

A statistical analysis was carried out first to identify statistically significant differences following biochar amendment for all crop and soil combinations by comparing each treatment to the respective control treatment. These results are displayed in figure in Section 3.2. Further more differences between all treatments for each soil and crop combination were identified and are reported in the text. All analyses were carried out at the $p<0.05$ level using $t$ tests and analysis of variance carried out using Microsoft excel. 


\section{Results and Discussion}

\subsection{Biochar and Soil Physico-Chemical Properties}

\subsubsection{Rice Husk Biochar Properties}

The physico-chemical characteristics of the rice husk biochars and soils are shown in Tables 1 and 2 respectively. The total carbon content of the Belonio Biochar (B) was much higher (49\%) than that of the rice mill char $(\mathrm{R} ; 16 \%)$ showing that rice husk biochar produced via a controlled pyrolysis process underwent a more carbon efficient carbonization process than the gasification process that occurred in the rice processing mill. This fact is also confirmed by the much higher ash content of the $\mathrm{R}(75 \%)$ than that of the B (38\%) biochar. This difference indicates that there was a greater amount of oxidation reactions taking place in the cyclonic gasification unit at the rice processing mill (aimed at maximal energy generation with the biochar as a byproduct), compared to the oxidation reactions taking place for the Belonio pyrolysis unit (which is specifically designed to give maximum biochar yield). Both biochars were alkaline and had $\mathrm{pH}$ greater than 8 , with $\mathrm{R}$ biochar being slightly more alkaline than B biochar (10.2 for R and 8.9 for B). Titration curves for biochar suspensions (Figure S6 in the Supplementary Materials) indicate that both biochars had the ability to neutralize acid. $\mathrm{R}$ biochar had a stronger buffering capacity $\left(4.2 \mathrm{mmol} \mathrm{H}^{+}\right)$at $\mathrm{pH} 6.2$ as compared to $\mathrm{B}\left(2.5 \mathrm{mmol} \mathrm{H}^{+}\right)$, likely as the result of the higher ash content of $R$. The biochars had low bulk densities of 0.13 for $R$ and 0.12 for $\mathrm{B}$ and very low $\mathrm{N}$ contents of $0.25 \%$ for $\mathrm{R}$ and $0.76 \%$ for $\mathrm{B}$. Water retention curves showed that plant available water (PAW) of R was greater (107 wt \%) than that of B (96 wt \%) (shown in Figure 1).

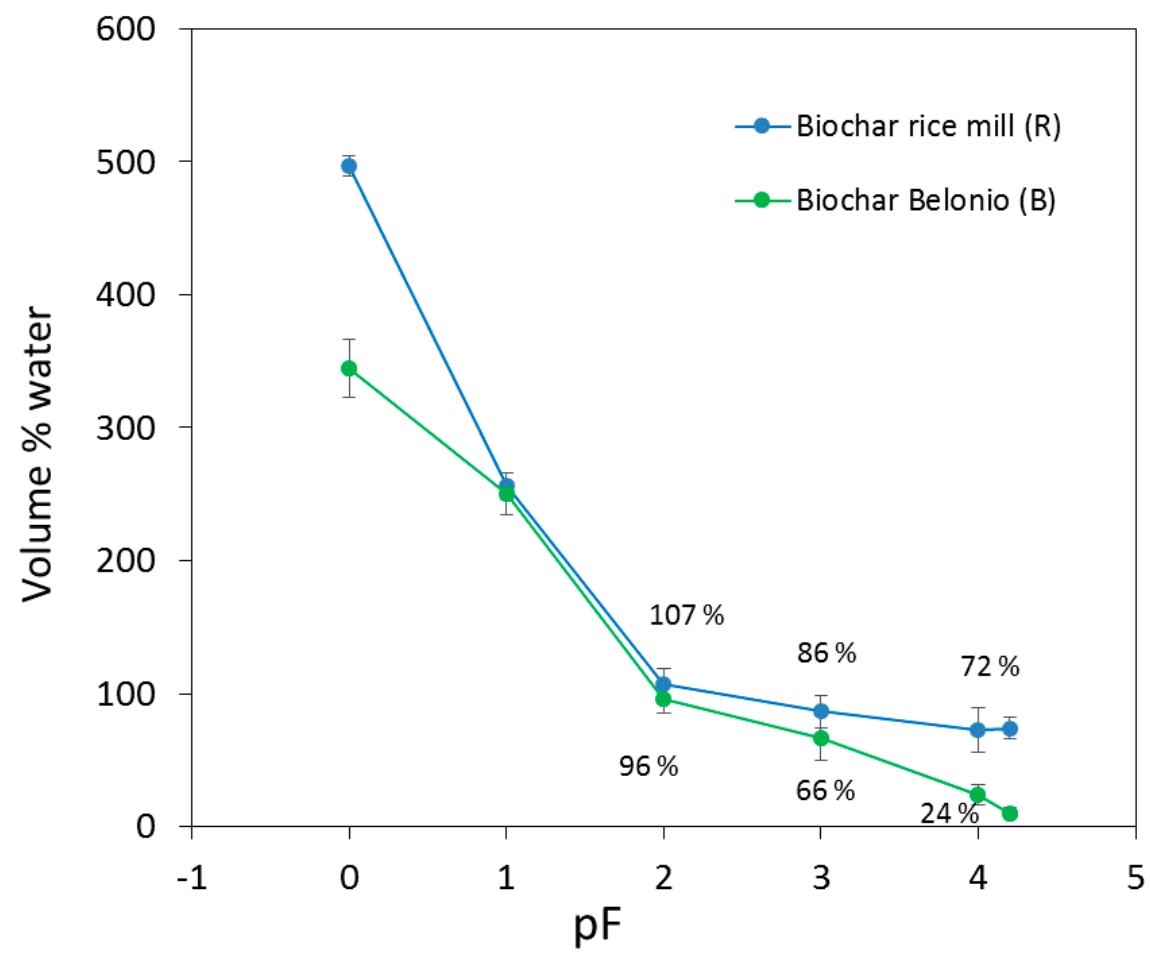

Figure 1. $\mathrm{pF}$ curves, water retention capacity of the rice husk biochars. $\mathrm{R}=$ rice husk biochar from local mill, B = rice husk biochar from Belonio pyrolysis unit. 
Table 1. Biochar properties.

\begin{tabular}{|c|c|c|c|c|c|c|c|c|c|c|c|c|c|c|}
\hline & & $\mathrm{pH}$ & $\begin{array}{c}\text { Total C } \\
(\%)\end{array}$ & $\begin{array}{c}\text { Total N } \\
(\%)\end{array}$ & $\begin{array}{c}\text { CEC } \\
\text { (cmol/kg Soil) }\end{array}$ & $\begin{array}{c}\text { Bulk Density } \\
\left(\mathrm{g} / \mathrm{cm}^{3}\right)\end{array}$ & Ash (\%) & $\begin{array}{c}\text { Alkalinity } \\
\text { (cmol + kg/Soil) }\end{array}$ & $\begin{array}{c}\mathrm{Ca}^{2+} \\
(\mathrm{mg} / \mathrm{kg})\end{array}$ & $\begin{array}{l}\mathrm{Mg}^{2+} \\
(\mathrm{mg} / \mathrm{kg})\end{array}$ & $\begin{array}{c}\mathrm{K}^{+} \\
(\mathrm{mg} / \mathrm{kg})\end{array}$ & $\begin{array}{c}\mathrm{Na}^{+} \\
(\mathrm{mg} / \mathrm{kg})\end{array}$ & $\begin{array}{l}\mathrm{Al}^{3+} \\
(\mathrm{m} / \mathrm{kg})\end{array}$ & $\begin{array}{c}\mathrm{Ca} / \mathrm{Al} \\
\text { Molar Ratio }\end{array}$ \\
\hline $\begin{array}{l}\text { Rice mill } \\
\text { biochar }\end{array}$ & $\mathrm{R}$ & 10.2 & 16 & 0.25 & 13.2 & 0.13 & 75 & 40 & 45 & 980 & 870 & 190 & $<0.1$ & $>100$ \\
\hline Belonio Biochar & B & 8.9 & 49 & 0.76 & 10.1 & 0.12 & 38 & 35 & 32 & 50 & 90 & 100 & $<0.1$ & $>100$ \\
\hline
\end{tabular}

Table 2. Soil properties at harvesting.

\begin{tabular}{|c|c|c|c|c|c|c|c|c|c|c|c|c|c|c|c|}
\hline \multirow[b]{2}{*}{ Crop/soil } & \multirow[b]{2}{*}{ Trt } & \multicolumn{7}{|c|}{ Pot Trial Season 1} & \multicolumn{7}{|c|}{ Pot trial Season 2} \\
\hline & & $\mathrm{pH}$ & $\begin{array}{c}\text { CEC } \\
\text { (cmol + kg/Soil) }\end{array}$ & $\begin{array}{c}\text { Total Soil } \\
\text { Leachate (L) }\end{array}$ & $\begin{array}{l}\text { Water at } \\
\text { Field } \\
\text { Capacity }\end{array}$ & $\begin{array}{c}\text { Plant } \\
\text { Available } \\
\text { Water (PAW) }\end{array}$ & $\mathrm{Ca} / \mathrm{Al}$ & $\begin{array}{c}\text { Total } \\
\text { Microbial Count } \\
\left(\log \mathrm{Cfu} 1 \times 10^{5}\right)\end{array}$ & $\mathrm{pH}$ & $\underset{\text { kg/Soil) }}{\text { CEC (cmol + }}$ & $\begin{array}{c}\text { Total Soil } \\
\text { Leachate (L) }\end{array}$ & $\begin{array}{c}\text { Water } \\
\text { at Field } \\
\text { Capacity }\end{array}$ & $\begin{array}{c}\text { Plant } \\
\text { Available } \\
\text { Water (PAW) }\end{array}$ & $\mathrm{Ca} / \mathrm{Al}$ & $\begin{array}{c}\text { Total } \\
\text { Microbial Count } \\
\left(\log \mathrm{Cfu} 1 \times 10^{5}\right)\end{array}$ \\
\hline \multirow{5}{*}{$\begin{array}{l}\text { Corn/Acid } \\
\text { sulfate }\end{array}$} & C & $5.1 \pm 0.33 \mathrm{~b}$ & $15.2 \pm 0.46^{\mathrm{b}}$ & \multirow{5}{*}{${ }^{*}$} & \multirow{5}{*}{ * } & \multirow{5}{*}{ * } & $1.29 \pm 0.08^{b}$ & $4.41 \pm 0.42^{\mathrm{c}}$ & $5.3 \pm 0.29 \mathrm{a}$ & $17.9 \pm 0.96 \mathrm{a}$ & \multirow{5}{*}{ * } & \multirow{5}{*}{ * } & \multirow{5}{*}{ * } & $2.4 \pm 0.34 \mathrm{c}$ & $5.1 \pm 0.37^{a}$ \\
\hline & B2 & $5.2 \pm 0.28^{b}$ & $17.0 \pm 0.38^{\mathrm{a}}$ & & & & $1.82 \pm 0.06^{b}$ & $5.82 \pm 0.05 \mathrm{a}, \mathrm{b}$ & $5.4 \pm 0.95^{\mathrm{a}}$ & $18.0 \pm 0.85^{\mathrm{a}}$ & & & & $4.8 \pm 0.92 \mathrm{~b}$ & $5.3 \pm 0.48^{\mathrm{a}}$ \\
\hline & B5 & $5.9 \pm 0.29 \mathrm{a}, \mathrm{b}$ & $16.5 \pm 0.46^{\mathrm{a}}$ & & & & $3.55 \pm 0.42 \mathrm{a}$ & $6.30 \pm 0.43 \mathrm{a}$ & $5.5 \pm 0.46^{\mathrm{a}}$ & $18.2 \pm 0.94 \mathrm{a}$ & & & & $6.9 \pm 0.93 \mathrm{a}, \mathrm{b}$ & $4.9 \pm 1.42 \mathrm{a}, \mathrm{b}$ \\
\hline & R2 & $5.5 \pm 0.30^{\mathrm{a}}$ & $16.9 \pm 0.66^{\mathrm{a}}$ & & & & $1.55 \pm 0.58 \mathrm{~b}$ & $5.51 \pm 0.65^{b}$ & $5.7 \pm 0.45^{\mathrm{a}}$ & $17.3 \pm 0.47^{\mathrm{a}}$ & & & & $4.5 \pm 0.48 \mathrm{~b}$ & $4.8 \pm 0.38 \mathrm{a}, \mathrm{ab}$ \\
\hline & R5 & $5.8 \pm 0.26^{\mathrm{a}}$ & $15.7 \pm 1.03^{\mathrm{b}}$ & & & & $2.37 \pm 0.37 \mathrm{a}, \mathrm{b}$ & $5.84 \pm 0.32 \mathrm{a}, \mathrm{ab}$ & $5.9 \pm 0.39 \mathrm{a}$ & $17.7 \pm 0.66^{\mathrm{a}}$ & & & & $6.3 \pm 0.30 \mathrm{a}, \mathrm{b}$ & $5.2 \pm 0.35$ a \\
\hline \multirow{5}{*}{ Corn/Sandy } & $\begin{array}{ll}c \\
\end{array}$ & $4.9 \pm 0.84 \mathrm{~b}$ & $4.4 \pm 0.16^{c}$ & $1.28 \pm 0.11 \mathrm{a}$ & $5.4 \pm 0.75^{c}$ & $4.3 \pm 0.45^{b}$ & $12.7 \pm 0.54^{b}$ & $3.40 \pm 0.59 \mathrm{~b}$ & $5.5 \pm 0.26^{\mathrm{a}}$ & $4.5 \pm 0.15^{b}$ & $1.2 \pm 0.62^{\mathrm{a}}$ & $5.5 \pm 0.28^{\mathrm{c}}$ & $4.7 \pm 0.24 \mathrm{~b}$ & $10.7 \pm 0.72^{c}$ & $4.7 \pm 0.49^{b}$ \\
\hline & B2 & $5.1 \pm 0.26^{b}$ & $5.1 \pm 0.27 \mathrm{~b}$ & $1.01 \pm 0.13 \mathrm{~b}$ & $13.3 \pm 0.16^{b}$ & $5.7 \pm 0.30 \mathrm{a}$ & $18.0 \pm 0.53 \mathrm{~b}$ & $6.21 \pm 0.27 \mathrm{a}$ & $5.8 \pm 0.31 \mathrm{a}$ & $4.7 \pm 0.16^{\mathrm{a}}$ & $1.0 \pm 0.13 \mathrm{a}, \mathrm{b}$ & $9.4 \pm 0.47^{b}$ & $6.2 \pm 0.23 \mathrm{a}, \mathrm{b}$ & $20.9 \pm 0.21 \mathrm{~b}$ & $5.0 \pm 0.37 \mathrm{a}, \mathrm{b}$ \\
\hline & B5 & $5.5 \pm 0.15^{\mathrm{a}, \mathrm{b}}$ & $6.6 \pm 0.44^{\mathrm{a}}$ & $0.82 \pm 0.23 \mathrm{~b}, \mathrm{c}$ & $15.3 \pm 0.42^{\mathrm{a}}$ & $6.2 \pm 0.25^{\mathrm{a}}$ & $34.4 \pm 4.75 \mathrm{a}$ & $6.15 \pm 0.34 \mathrm{a}$ & $5.4 \pm 0.20^{a}$ & $5.2 \pm 0.27^{\mathrm{a}}$ & $0.9 \pm 0.19 \mathrm{~b}$ & $9.2 \pm 0.20^{b}$ & $8.2 \pm 0.30$ a & $26.3 \pm 1.72^{a, b}$ & $4.8 \pm 0.15^{\mathrm{b}}$ \\
\hline & R2 & $6.0 \pm 0.22 \mathrm{a}$ & $4.90 \pm 0.33^{\mathrm{b}}$ & $0.67 \pm 0.11 \mathrm{c}$ & $13.3 \pm 0.53 \mathrm{~b}$ & $5.7 \pm 0.32^{\mathrm{a}}$ & $11.7 \pm 0.94 \mathrm{~b}$ & $5.52 \pm 0.27 \mathrm{a}, \mathrm{b}$ & $5.6 \pm 0.26^{\mathrm{a}}$ & $4.9 \pm 0.30 \mathrm{a}$ & $1.0 \pm 0.15 \mathrm{a}, \mathrm{b}$ & $5.7 \pm 0.61^{\mathrm{C}}$ & $5.4 \pm 0.36^{\mathrm{b}}$ & $21.7 \pm 2.34 \mathrm{~b}$ & $5.4 \pm 0.46^{\mathrm{a}}$ \\
\hline & $\mathrm{R} 5$ & $6.1 \pm 01.9^{\mathrm{a}}$ & $6.1 \pm 0.23 \mathrm{a}, \mathrm{b}$ & $0.69 \pm 0.17^{\mathrm{c}}$ & $15.6 \pm 0.39^{\mathrm{a}}$ & $6.55 \pm 0.20^{\text {a }}$ & $30.6 \pm 6.39^{\mathrm{a}}$ & $5.90 \pm 0.15^{\mathrm{a}}$ & $5.6 \pm 0.16^{\mathrm{a}}$ & $4.9 \pm 0.43^{\text {a }}$ & $0.8 \pm 0.25^{\mathrm{b}}$ & $12.5 \pm 0.46^{\mathrm{a}}$ & $7.0 \pm 0.22^{\mathrm{b}}$ & $43.7 \pm 1.12^{\mathrm{a}}$ & $5.6 \pm 0.11^{\mathrm{a}}$ \\
\hline \multirow{4}{*}{$\begin{array}{c}\text { Rice/Acid } \\
\text { sulfate }\end{array}$} & $\mathrm{C}$ & $4.6 \pm 0.35^{b}$ & $14.9 \pm 0.26^{\mathrm{c}}$ & \multirow{4}{*}{$*$} & & \multirow{4}{*}{$*$} & $2.28 \pm 0.21 \mathrm{~b}$ & $3.92 \pm 0.42 \mathrm{~b}$ & $4.3 \pm 0.25 \mathrm{a}$ & $14.6 \pm 0.33 \mathrm{~b}$ & \multirow{4}{*}{ * } & \multirow{4}{*}{ * } & & $2.460 .20 \mathrm{~b}$ & $4.70 .42 \mathrm{~b}$ \\
\hline & B2 & $4.9 \pm 0.07^{b}$ & $19.8 \pm 2.08 \mathrm{a}, \mathrm{b}$ & & & & $2.60 \pm 0.31 \mathrm{~b}$ & $3.4 \pm 0.15^{\mathrm{b}}$ & $4.5 \pm 0.11^{\mathrm{a}}$ & $15.2 \pm 0.46 \mathrm{a}, \mathrm{b}$ & & & & $3.14 \pm 0.61 \mathrm{a}, \mathrm{b}$ & $5.6 \pm 0.48 \mathrm{a}$ \\
\hline & B5 & $5.2 \pm 0.20$ a,b & $\begin{aligned} 23.7 \pm 2.71 \mathrm{a} \\
\end{aligned}$ & & & & $5.14 \pm 0.6^{\mathrm{a}}$ & $5.11 \pm 0.23 \mathrm{a}$ & $4.8 \pm 0.69^{a}$ & $15.2 \pm 0.22 \mathrm{a}, \mathrm{b}$ & & & & $4.17 \pm 0.19 \mathrm{a}$ & $4.8 \pm 0.43 \mathrm{~b}$ \\
\hline & $\begin{array}{l}\mathrm{R} 2 \\
\mathrm{R} 5\end{array}$ & $\begin{array}{l}5.3 \pm 0.40^{\mathrm{a}} \\
55+03 \mathrm{a}\end{array}$ & $\begin{array}{c}18.1 \pm 1.74 \mathrm{a}, \mathrm{b} \\
169+01 \mathrm{~b}^{\mathrm{b}}\end{array}$ & & & & $1.15 \pm 0.80^{\mathrm{b}}$ & $\begin{array}{l}4.53 \pm 0.21 \mathrm{a}, \mathrm{b} \\
588+040 \mathrm{a}\end{array}$ & $4.5 \pm 0.09^{a}$ & $16.9 \pm 0.48^{\mathrm{a}}$ & & & & $2.91 \pm 0.61 \mathrm{~b}$ & $5.4 \pm 0.38 \mathrm{a}$ \\
\hline
\end{tabular}

Corn AS = Corn planted under acid sulfate soil, Corn $\mathrm{S}$ = corn planted under sandy soil, Rice AS = Rice planted under acid sulfate soil. Means within the same column in each crop set

followed by same letters $(\mathrm{a}, \mathrm{b}, \mathrm{c})$ are not significantly different at $p<0.05 .{ }^{*}$ Value was not measured. 


\subsubsection{Soil Properties}

Table 2 shows the properties of the soils without the amendment of biochar after the first and second harvest (labeled as control $C$ for all treatments). Both the acid sulfate soil and the sandy soil had low $\mathrm{pH}$ values (between 4.6 and 5.1). The $\mathrm{C}$ content and the CEC of the acid sulfate soil (5.5\% and $15 \mathrm{cmolc} / \mathrm{kg}$, respectively) were higher than those of the sandy soil $(1.8 \%$ and $4.4 \mathrm{cmolc} / \mathrm{kg})$. The acid sulfate soil had significant amounts of available $\mathrm{Al}^{3+}$, and its molar ratios of beneficial $\mathrm{Ca}^{2+}$ vs. deleterious $\mathrm{Al}^{3+}$ were between 0.9 and 1.7 with a small variation between crop type and season. For the sandy soil this ratio was much higher ( $>7)$, indicating that $\mathrm{Al}$ toxicity for this soil was not an agronomic problem. The amounts of exchangeable Na were relatively high (Table S2 in the Supplementary Materials), around 2.6 to $6 \mathrm{meq} / \mathrm{kg}$, but these values showed no trend with varying biochar amendment, indicating that they were rather a result of irrigation and evapotranspiration than of biochar amendment. Evapotranspiration in the sandy soil was rather high, since almost $34 \mathrm{~L}$ of water were added in total whereas only around $1 \mathrm{~L}$ was recovered as soil leachate (Table 2).

\subsection{The Effect of Rice Husk Biochar Amendment on the Yield of Corn and Rice}

The crop yield is expressed in $t /$ ha fresh weight (as shown in Table S3 in the Supplementary Materials) and was calculated from the yield expressed as $\mathrm{g} /$ pot. Results of crop yields for both crops for all biochar amendments and for both cropping seasons are shown in Figure 2 as the relative change in yield following biochar amendment as compared to the respective control treatment.
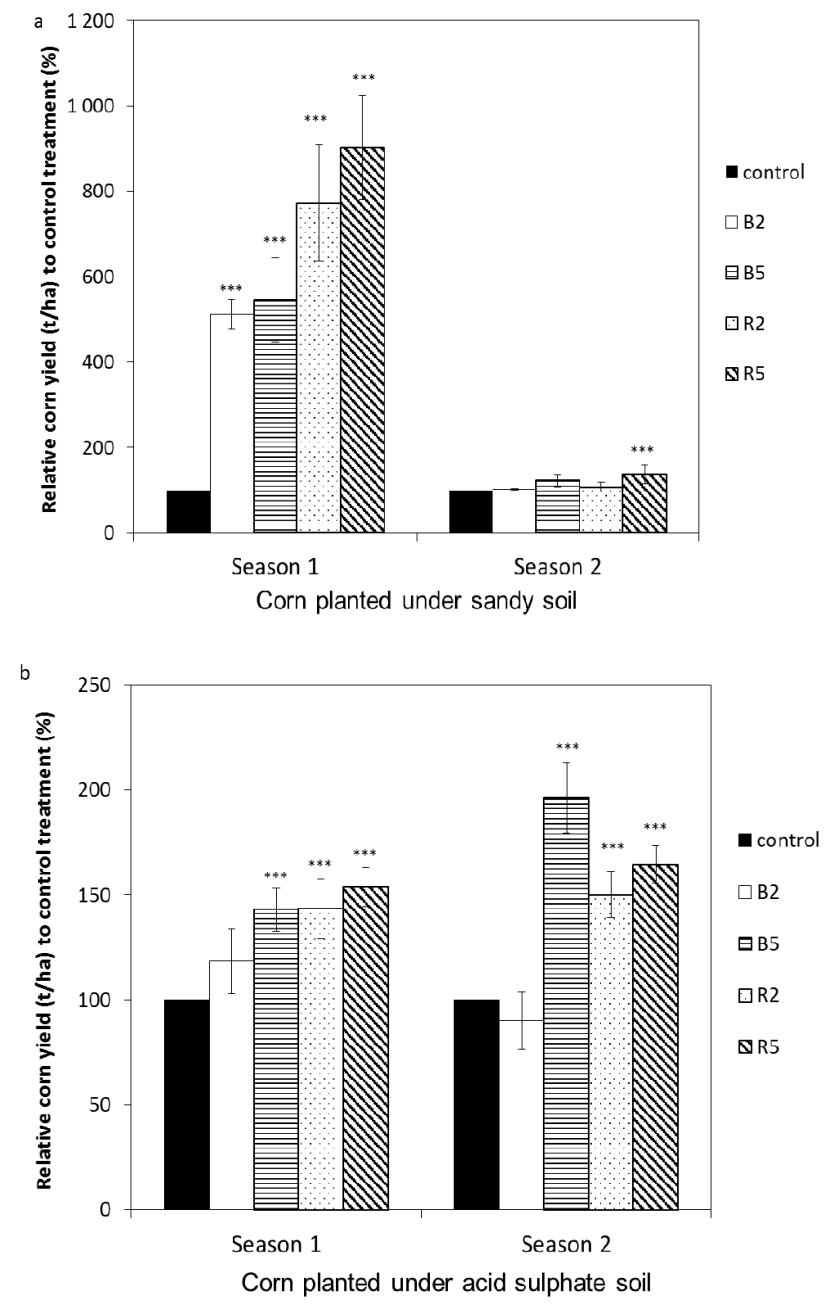

Figure 2. Cont. 




Figure 2. Relative yield of corn planted under sandy soil (a); corn planted under acid sulfate soil (b); and rice planted under acid sulfate soil (c) compared to the respective control treatment and plotted as percentage. The control treatments are set to $100 \%$ and differences relative to this are shown. Significant differences ( 0.05 level) compared to the respective control for each crop and soil combination and for each season are indicated with $* * *$.

\subsubsection{Sandy Soil Cropped with Corn}

For the sandy soil cropped with corn, yields determined for the first cropping season were significantly increased following the amendment of rice husk biochar in the following order of treatments; R5 = R2 > B5 = B2 >> C. The yield of corn ( $\mathrm{t} / \mathrm{ha}$ ) in the presence of biochar was significantly higher than that of the control at both $2 \%$ and $5 \%$ dosages, with also statistically higher yields in the presence of the R (rice mill) biochar compared to the B (Belonio) biochar (absolute yields are shown in Table S3 in the Supplementary Materials). For the second cropping season, a slightly different trend was observed $(\mathrm{R} 5=\mathrm{B} 5>\mathrm{R} 2=\mathrm{B} 2=\mathrm{C})$. In the second cropping season, the yield of corn without biochar in the $C$ treatment was higher than in season $1(0.02 t /$ ha for cropping season 1 compared to $0.2 t / h a$ for cropping season 2), and thus relative increases following the amendment of biochar were smaller. This could have been caused by better growing conditions in season two, however as none of the other treatments (different soil and crop) showed the same pattern, this can not be confirmed. Biochar is considered a stable amendment material, where half lives can be up to hundreds of years [23] and thus a prolongs positive effect of amendment could be anticipated. These results for sandy soil cropped with corn can not confirm a prolonged effect of biochar amendment. However the other variables used in this study support a prolonged effect (see below).

There were differences in the response of corn to the different biochar doses and types, although they were not completely consistent over both cropping season. The effect of biochar dose in the second season was clearer than in the first, where a larger biochar dose resulted in a greater yield (although not statically significant compared to the control for B5). However this was not the case for season one. Previous studies have reported a better effect of biochar amendment when a larger dose is applied. Cornelissen et al. [4] showed that the addition of higher biochar rates of $4 \mathrm{t} / \mathrm{ha}$ gives higher yield of maize cropped under sandy soil compared to application rates of $0.8 \mathrm{t} / \mathrm{ha}$. Whilst these biochar amendment levels are lower than those used in this experiment, the tropical problematic sandy soil from Zambia used provides a warrant comparison to this study. Syuhada et al., 2015 reported with the addition of biochar under sandy spodosol, nutrient uptake by corn was increased significantly (personal communication). In this pot trial, there was a difference in effect based on biochar type where $\mathrm{R}$ biochar produced the most beneficial effects for corn cropped under sandy soil, especially in the first season. In sandy soils, agronomic limitations caused by excess $\mathrm{Al}$ and $\mathrm{N}$ deficiency are not expected, however a low organic matter content, a low CEC and drought stress 
due to high water drainage are common problems. The addition of both biochars to this sandy soil allowed some of these problems to be overcome (as further discussed below). The improvement in soil $\mathrm{pH}$, exchangeable cations, microbial community, plant-available water and nutrient availability following amendment of biochar can be cited as the reasons for the increase in yield of corn cropped in the sandy soil. Previous studies have reported beneficial effects of the amendment of biochar to sandy soils. Krishnakumar et al. [24] reported that positive impacts of biochar applications included; improved soil structure, retention of nutrients in soil, increased soil CEC, soil $\mathrm{pH}$, nutrient use efficiency, water holding capacity, presence of beneficial microbes and a reduced greenhouse gas emission. Petter et al. [25] reported improvements in soil fertility of a sandy loam soil following biochar amendment, with the largest effects felt on the soil surface layer and in the first year after biochar was incorporated into the soil.

\subsubsection{Acid Sulfate Soil Cropped with Corn and Rice}

The amendment of rice husk biochar to the acid sulfate soil also significantly increased the yield of corn and rice as compared to the unamended control for several treatments. For corn the effect of biochar amendment increased in the following order of treatments for cropping season one; $\mathrm{R} 5>\mathrm{R} 2=\mathrm{B} 5>\mathrm{B} 2=\mathrm{C}$, and for cropping season two; B5 $>\mathrm{R} 2=\mathrm{R} 5>\mathrm{B} 2=\mathrm{C}$ R5. In this instance it seems that there is a positive relationship between crop yield and biochar dose. Following amendment of rice husk biochar to acid sulfate soil cropped with rice, the effect of biochar amendment increased in the following order of treatments; for season one, B5 = R5 > B2 = R2 = C, and for season two the large standard deviations meant that the effect of biochar amendment was no longer statistically significantly different to the unamended control (apart from B2) and thus; B2 $>$ R2 = B5 = R5 = C. However, the yield was the greatest for the lower doses of biochar amendment. The reversal of the trend with time could in part be explained by a more efficient extraction of nutrients by the rice grown in the pots with the higher dose in the first season leading to a slightly nutrient deficient soil for the second season and hence a reduction in growth for the higher dose. Overall there were modest but sometimes statistically significant increases in yield for the rice cropped on acid sulfate soil, when compared to the control treatment. The yield increases for the acid sulfate soil are probably a consequence of acidity alleviation, expressed by the significant increases in $\mathrm{Ca} / \mathrm{Al}$ ratios, especially for the $5 \%$ biochar amendments (Table 1, see next section). For both crops and acid sulfate soil, the positive overall effect of biochar amendment is felt in both cropping seasons. This result implies that the agricultural benefits of adding biochar (acid alleviation, water retention, see below for more discussion) are sustained with time for this soil. This result is corroborated by Zhang et al., 2012 who reported a positive effect of biochar amendment on soil quality and rice yield over two cycles of rice cropping for an Anthrasol from China [26].

\subsection{The Effect of the Amendment of Rice Husk Biochar on Soil Physical, Chemical and Biological Properties}

The changes in physico-chemical properties following the amendment of rice husk biochar at $2 \%$ and 5\% dose of the acid sulfate and sandy soil are shown in Table 2 and Figure 3 (pF curves).

\subsubsection{Soil $\mathrm{pH}$}

The sandy soil cropped with corn in season 1 showed a significant increase in soil $\mathrm{pH}$ from the initial $\mathrm{pH}$ of 4.9 for all of the rice husk biochar treatments; the increase was stronger for $\mathrm{R}$ biochar (6.0-6.1) than for B biochar (5.1-5.5). This $\mathrm{pH}$ effect might in part explain the corn yields that are greater for R5 and R2 than for B5 and B2 in season one. However, exchangeable toxic $\mathrm{Al}^{3+}$ in the sandy soil was low and $\mathrm{Ca} / \mathrm{Al}$ ratios high ( $>7$; Table 2$)$, so $\mathrm{pH}$ is not likely to be the primary factor explaining positive yield effects of biochar in the sandy soil.

For the acid sulfate soil cropped with corn the $\mathrm{pH}$ was increased the most following $5 \%$ amendment of both biochars (from 5.1 in the control to 5.9 for B5 and 5.8 for R5). For the acid sulfate soil cropped with rice the greatest $\mathrm{pH}$ increase was observed following the amendment of 
$\mathrm{R} 5$ in cropping season one and $\mathrm{B} 5$ in cropping season two. The $\mathrm{pH}$ decreased from season one to two, suggesting that the biochar was not able to provide the same acid neutralizing capacity (see Figure S6 in the Supplementary Materials) over time, despite the slightly better effect on rice yield in season 2. Other authors have reported increases in $\mathrm{pH}$ following the amendment of biochar to acidic soils. Alling et al. [27] reported such increases for acidic soils from Indonesia where in general a higher $\mathrm{pH}$ and higher $\mathrm{Ca} / \mathrm{Al}$ ratios resulted from a larger biochar dose.

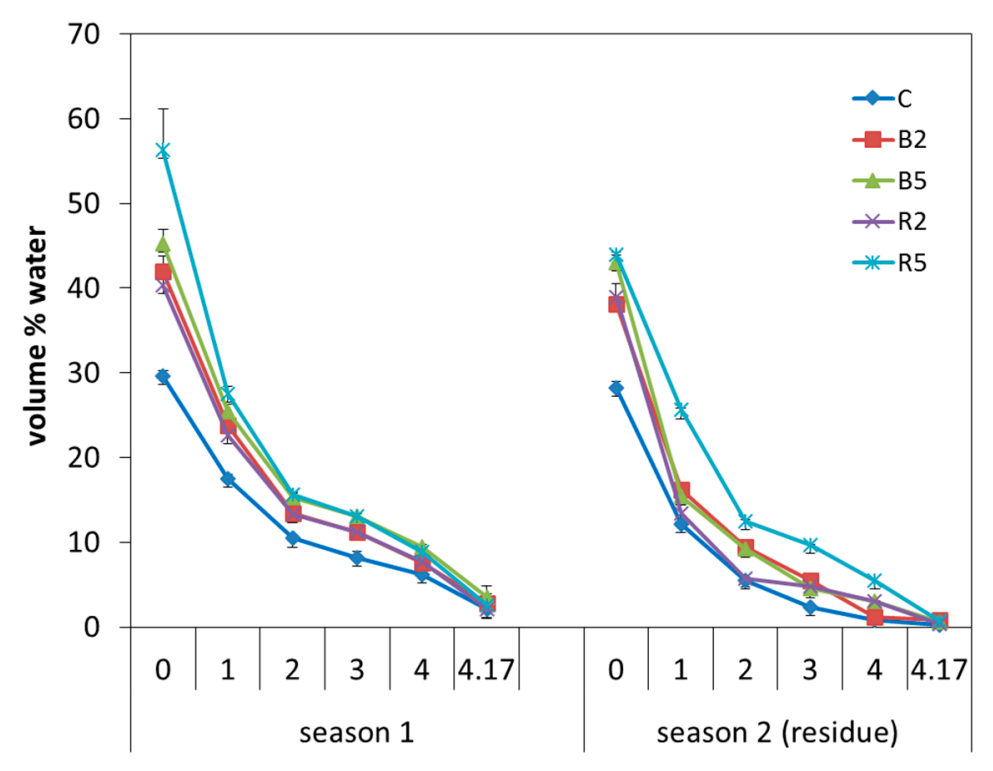

$\mathrm{pF}=\log ($ soil water pressure $\mathrm{cm} \mathrm{H2O}$ )

Figure 3. Water retention curves of sandy soil planted with corn. Plant available water is between pF 2 (field capacity) and pF 4.2 (wilting point). Error bars represent standard deviations of triplicate measurements.

Acid sulfate soils are particularly vulnerable to $\mathrm{Al}$ toxicity as they are characterized by high concentrations of $\mathrm{Al}^{3+}, \mathrm{Fe}^{3+}$, and $\mathrm{H}^{+}$at soil $\mathrm{pH}<5$, high $\mathrm{P}$ fixation, low organic matter content and generally low microorganisms activity [28]. High $\mathrm{Al}^{3+}$ concentrations can impair crop growth, and limit root growth. The degree of $\mathrm{Al}^{3+}$ toxicity depends on the dissolved $\mathrm{Al}^{3+}$ concentration which is in turn related to the soil $\mathrm{pH}$ [27]. When biochar is added to acid sulfate soils basic compounds that are able to reduce soluble $\mathrm{Al}^{3+}$ are also added. Table S2 in the Supplementary Materials shows that there were significantly lower absolute concentrations of soil exchangeable $\mathrm{Al}^{3+}$ for the biochar-amended soils compared to the control ones, for both crops and cropping seasons. The molar $\mathrm{Ca} / \mathrm{Al}$ ratio is often used as an indication of the plant toxicity level in acid soil. The $\mathrm{Ca} / \mathrm{Al}$ ratio for the unamended acid sulfate soil was low, between 0.9 and 1.7 (cropping season one and two, Table 2). Importantly, for both seasons and both biochars, the $5 \%$ amendments showed significant increases in $\mathrm{Ca} / \mathrm{Al}$ ratios of the acid sulfate soils. For corn cropped under acid sulfate soil the molar $\mathrm{Ca} / \mathrm{Al}$ ratio was highest for $\mathrm{B} 5$ (2.4) after cropping season one and this value increased after cropping season two to 4.7. For the rice cropped under acid sulfate soil the greatest increase was felt for R5 treatment ( 3.5 after cropping season one and 3.1 after cropping season two). This is an indication that the main mechanism of biochar effectiveness in acid sulfate soils is aluminum root stress alleviation.

In addition to exchangeable base cations, the addition of the ash fraction of biochar to the soil is also a reason why the $\mathrm{pH}$ was increased following amendment. A dissolution of alkaline carbonate, silicates, oxides and hydroxide minerals present mainly in the ash fraction of the biochar could have occurred in the pot experiment. The $\mathrm{R}$ biochar had a higher ash content of $75 \%$ compared to $\mathrm{B}$ explaining the larger increase in $\mathrm{pH}$ for the $\mathrm{R}$ than the $\mathrm{B}$ biochar. Ash is one component of biochar that 
is lost over time and has been cited as being important in explaining short-term impacts of biochar on crop growth [29]. These experiments only lasted for two seasons and this could not be tested extensively. However, based on the different ash contents, it the Belonio (B) biochar was expected to demonstrate the most positive long lasting effects since it contained the lower amount of soluble ash. This was indeed true for the highest B dose.

\subsubsection{Soil CEC and Exchangeable Bases}

Soil pH influences soil CEC and nutrient availability [4]. Increase in soil pH can increase the soil's ability to adsorb cations depending on the charge of soil's cation exchange complex [30]. In this study the changes in CEC caused by the amendment of rice husk biochars were significant for both biochars, both crops and both cropping seasons (largest increase was just under $8 \mathrm{cmol} / \mathrm{kg}$ for the rice cropped under acid sulfate soil in cropping season one for treatment B5, Table 2). In sandy soils, low CEC is one of the major agricultural problems that leads to continuously high application of fertilizers in order to meet crop requirements. Small but significant increases in CEC may have contributed to the increases in crop yield.

Table S2 in the Supplementary Materials shows the changes in exchangeable bases following biochar amendment. Potassium $\left(\mathrm{K}^{+}\right)$, magnesium $\left(\mathrm{Mg}^{2+}\right)$ and calcium $\left(\mathrm{Ca}^{2+}\right)$ concentrations were observed to increase following the amendment of rice husk biochars to both soils cropped with both crops and for both cropping seasons, with effects being most prominent for the $5 \%$ amendment. Laird et al. [31] reported that the addition of biochar to weathered soils (fine loamy, typic hapludolls) can increase exchangeable potassium via both the addition of potassium that is contained in the ash fraction of the biochar, and by binding potassium and thus reducing losses through leaching. Martinsen et al. [32] observed significantly higher K contents in both the soil solution and maize plant tissue after the amendment of biochar, corresponding to the amounts of $\mathrm{K}$ added via the biochar (68 kg/ha) amendment rather than via the addition of fertilizer $(28 \mathrm{~kg} / \mathrm{ha})$. Masulili 2010, [33] reported that the addition of $10 \mathrm{t} / \mathrm{ha}$ rice husk biochar to acid sulfate soil cropped with rice increases exchangeable calcium significantly compared to a control. Cornelissen et al. [4] also observed significant increases in $\mathrm{Ca} / \mathrm{Al}$ ratios upon biochar amendment to weathered tropical soils.

\subsubsection{Plant-Available Water}

The water holding capacity of sandy soils is often a major problem that can result in a decrease in crop productivity as excessive drainage of sandy soils can lead to inefficient water and nutrient uptake by crops. In this study, plant available water (PAW) was therefore only measured for the sandy soil and results are shown in Figure 3. PAW significantly increased following the amendment of both rice husk biochars compared to the control unamended soil and was largest for the $5 \%$ amendment (from 4.3 weight percent water in the $\mathrm{C}$ to $6.6 \%$ for $\mathrm{R} 5$ and $6.2 \%$ for $\mathrm{B} 5$ for season one and from $4.7 \%$ in the $\mathrm{C}$ to $7.0 \%$ for R5 and $8.8 \%$ for B5 for season two). It is interesting to note that the PAW was higher in cropping season two (although not as high as for cropping season one) for the biochar treatments than the control, even though the biochar was not reapplied. The decrease in effectiveness could be due to a migration of the rice husk biochar from the subsoil layer and further down in to the soil profile, however this was not explicitly monitored. The increase in PAW for all treatments was corroborated by a decrease in leachate collected from the amended pots compared to the control $(1.28 \mathrm{~L}$ for $\mathrm{C}, 0.69 \mathrm{~L}$ for R5, $0.82 \mathrm{~L}$ for B5, $0.69 \mathrm{~L}$ for R2 and 1.01 for B2 for cropping season one).

These results suggest that the increase in PAW caused by the amendment of biochar is one of the explanatory factors for the observed increase in corn yield cropped on the sandy soil. Such a finding is supported by previous studies, amongst others Carvalho et al. [34] who reported an increase in PAW in the upper soil layer following biochar amendment and related this observation to an increase in the overall porosity of the soil matrix caused by the biochar amendment. Cornelissen et al. [4] and Martinsen et al. [32] reported similar findings where the addition of $5 \%$ biochar significantly increased the PAW of three sandy soil in West Zambia, from 9\% to 15\% in the most sandy soil. 


\subsubsection{Soil Microbial Population}

The soil microbial population is an important indicator of soil health and biochar can exert a positive or negative effect on this parameter [28]. The sandy nature of the spodosol used in this study, combined with its very low organic matter and carbon content may not provide a conducive environment for native microbial communities. Following the amendment of rice husk biochar to the sandy soil, a significantly larger microbial population (total count) was observed in the order; $\mathrm{B} 2=\mathrm{R} 5=\mathrm{B} 2=\mathrm{R} 2>\mathrm{C}$ for cropping season one, the differences disappearing in season two (Table 2). Similar trend of significantly higher microbial counts upon biochar amendment in season one but not in season two were observed for the acid sulfate soil cropped with both rice and corn. The positive effect of rice husk biochar amendment to sandy and acid sulfate soils in this study may indicate that the positive chemical and physical effects created by the biochar amendment (mainly acidity alleviation, nutrient contents and plant available water) affect the biology of the system offering a habitat for the microorganisms. However, since the effect on the microbial population diminished with time, the sustained positive physico-chemical effects may not be mirrored by the biological effects. Additional analysis is needed to investigate this and provide direct evidence that the rice husk biochar provides a habitat for the microbes.

\section{Conclusions}

The amendment of rice husk biochar to sandy and acid sulfate soils from Malaysia was found to improve soil physico-chemical properties and increase the yield of corn and rice. The rice husk biochar produced via a gasification process in a local rice mill possessed physico-chemical properties that were able to neutralize the acidic nature of the soils and contribute positively to the retention of water for the sandy soil. The rice husk biochar produced from a specially developed upscaled Belonio pyrolysis unit was also able to neutralize acidity but additionally reduced exchangeable $\mathrm{Al}^{3+}$. Beneficial effects of biochar amendment were in some cases felt over two cropping seasons, however not for each individual combination of variables tested in this study. Our initial results warrant further investigation of the use of biochar in a Malaysian setting. If biochar re-application is not needed after the first amendment clear benefits for farmers both with regards to cost and time would be felt. This case study shows that in the Kelantan region of Malaysia, biochar which is now considered as a waste, could be applied at local fields for the cultivation of rice under acid sulfate soils to improve yields, re-use a waste material and ultimately gain financially. Before wide scale implementation, the concentration of PAHs and PTE should be quantified in the biochar. Within this study the performance of rice husk biochar as a soil amendment in combination with the application of standard fertilizer rates was investigated. Further studies on the use of rice husk biochar fortified with nutrients from organic materials such as in Kammann et al. [35] and the additional aspect of variable fertilizer rates will provide more alternatives for the utilization of rice husk biochar for improved crop production in Malaysia.

Supplementary Materials: The following are available online at www.mdpi.com/2071-1050/7/12/15842/s1, Figure S1: Schematic diagram of cyclonic furnace in rice processing mill BERNAS Peringat, Kelantan., Figure S2: Complete randomized design for pot trials, Figure S3: Schematic of pot set up, Figure S4: Leachate chamber designed at inner bottom of pot, Figure S5: Photographs of pot trials. (a) sandy soil and corn; (b) acid sulphate soil and corn; (c) acid sulphate soil and rice, Figure S6: Acid neutralizing capacity of the two rice husk biochars, Table S1: Standard fertilizer types and rates used for acid sulphate and sandy soil for corn and rice, Table S2: Soil exchangeable bases at harvest, Table S3: Yields of corn cropped under acid sulphate and sandy soil, and rice cropped under acid sulphate soil ( $\mathrm{t} / \mathrm{ha}$ ) including the standard deviation of 4 measurements.

Acknowledgments: The Norwegian Research Council is gratefully acknowledged for funding the study through project 203901 in the program NorGlobal Environment-Energy-Climate, as well as project 217918, in the program FriPro.

Author Contributions: Theeba Manickam, Gerard Cornelissen and Sarah Hale conceived and designed the experiments; Theeba Manickam performed the experiments and data analysis; Illani Zuraihah Ibrahim analyzed the data; Robert Bachmann provided the biochar produced in the upscaled Belonio; Theeba Manickam and Sarah 
Hale predominately wrote the paper with input from Jan Mulder and Gerard Cornelissen; and Gerard Cornelissen and Sarah E. Hale secured the funding.

Conflicts of Interest: The authors declare no conflict of interest.

\section{References}

1. Lehmann, J.; Joseph, S. Biochar for Environmental Management. Science Technology and Implementation, 2nd ed.; Routledge Taylor and Francis Group: London, UK, 2015.

2. Manickam, T.; Bachmann, R.T.; Illain, Z.I.; Zulkefli, M.; Husni, M.H.; Samsuri, A.W. Characterization of local mill rice husk charcoal and its effect on compost properties. Malays. J. Soil Sci. 2012, 16, 89-102.

3. Liang, B.; Lehmann, J.; Solomon, D.; Kinyangi, J.; Grossman, J.; O’Neill, B.; Skjemstad, J.O.; Thies, J.; Luizao, F.J.; Petersen, J.; et al. Black carbon increases cation exchange capacity in soils. Soil Sci. Soc. Am. J. 2006, 70, 1719-1730. [CrossRef]

4. Cornelissen, G.; Martinsen, V.; Shitumbanuma, V.; Alling, V.; Breedveld, G.D.; Rutherford, D.; Sparrevik, M.; Hale, S.E.; Obia, A.; Mulder, J. Biochar effect on maize yield and soil characteristics in five conservation farming sites in zambia. Agron. J. 2013, 3, 256-274. [CrossRef]

5. Jeffery, S.; Verheijen, F.G.A.; van der Velde, M.; Bastos, A.C. A quantitative review of the effects of biochar application to soils on crop productivity using meta-analysis. Agric. Ecosyst. Environ. 2011, 144, $175-187$. [CrossRef]

6. Liu, X.; Zhang, A.; Ji, C.; Joseph, S.; Bian, R.; Li, L.; Pan, G.; Paz-Ferreiro, J. Biochar's effect on crop productivity and the dependence on experimental conditions-a meta-analysis of literature data. Plant Soil 2013, 373, 583-594. [CrossRef]

7. Nieuwolt, S. Climate and Agricultural Planning in Peninsular Malaysia (Special Report); Malaysian Agricultural Research \& Development Institute: Selangor, Malaysia, 1982; p. 139.

8. Enio, M.S.K.; Shamshuddin, J.; Fauziah, C.I.; Husni, M.H.A. Pyritization of the coastal sediments in the kelantan plains in the malay peninsula during the holocene. Am. J. Agric. Biol. Sci. 2011, 6, $393-402$. [CrossRef]

9. Jusop, S. Acid Sulfate Soils. Occurrence, Properties and Utilisation for Rice Production; Akademi Sains Malaysia: Kuala Lumpur, Malaysia, 2012.

10. Shamshuddin, J.; Muhrizal, S.; Fauziah, I.; van Ranst, E. A laboratory study of pyrite oxidation in acid sulfate soils. Commun. Soil Sci. Plant Anal. 2004, 35, 117-129. [CrossRef]

11. Panhwar, Q.A.; Naher, U.A.; Radziah, O.; Shamshuddin, J.; Razi, I.M. Bio-fertilizer, ground magnesium limestone and basalt applications may improve chemical properties of malaysian acid sulfate soils and rice growth. Pedosphere 2014, 24, 827-835. [CrossRef]

12. Shamshuddin, J.; Fauziah, C.I.; Arifin, A.; Rosenami, A.B. Effects of biochar application on the nutrients uptake of corn grown on sandy spodsols. Personal communication, 2015.

13. Hale, S.E.; Lehmann, J.; Rutherford, D.; Zimmerman, A.R.; Bachmann, R.T.; Shitumbanuma, V.; O’Toole, A.; Sundqvist, K.L.; Arp, H.P.H.; Cornelissen, G. Quantifying the total and bioavailable polycyclic aromatic hydrocarbons and dioxins in biochars. Environ. Sci. Technol. 2012, 46, 2830-2838. [CrossRef] [PubMed]

14. Carter, S.; Shackley, S.; Sohi, S.; Suy, T.B.; Haefele, S.M. The impact of biochar application on soil properties and plant growth of pot grown lettuce (Lactuca sativa) and cabbage (Brassica chinensis). Agron. J. 2013, 3, 404-418. [CrossRef]

15. Shackley, S.; Carter, S.; Knowles, T.; Middelink, E.; Haefele, S.M.; Sohi, S.; Cross, A.; Haszeldine, S. Sustainable gasification-biochar systems? A case-study of rice-husk gasification in cambodia, part I: Context, chemical properties, environmental and health and safety issues. Energy Policy 2012, 42, 49-58. [CrossRef]

16. Igarashi, T. Soil Improvement Effect of FMP E CRH in Indonesia; JICA Pamphlet; JICA: Tokoy, Japan, $1996 ;$ p. 30.

17. Oka, H.; Rungrattanakasin, W. Improvement of sandy soil in the northeast by using carbonized rice husks. ICA Tech. Rep. 1993, 13, 40-42.

18. Jaafar, N.M.; Clode, P.L.; Abbott, L.K. Soil microbial responses to biochars varying in particle size, surface and pore properties. Pedosphere 2015, 25, 770-780. [CrossRef]

19. Kameyama, K.; Miyamoto, T.; Shinogi, Y. Increases in available water content of soils by applying bagasse-charcoals. In Proceedings of the 19th World Congress of Soil Science, Soil Solutions for a Changing World, Brisbane, Australia, 1-6 August 2010. 
20. Steiner, C.; Teixeira, W.G.; Lehmann, J.; Nehls, T.; de Macedo, J.L.V.; Blum, W.E.H.; Zech, W. Long term effects of manure, charcoal and mineral fertilization on crop production and fertility on a highly weathered central amazonian upland soil. Plant Soil 2007, 291, 275-290. [CrossRef]

21. Kisiki, N.H.; Hale, S.E.; Cornelissen, G.; Bachmann, R.T. Designing and performance evaluation of biochar production in a top-lit updraft up-scaled gasifier. J. Sustain. Bioenergy Syst. 2015, 5, 41-55.

22. Chapman, H.D. Cation exchange capacity. In Methods of Soil Analysis; Black, C.A., Ed.; American Society of Agronomy: Madison, WI, USA, 1965; Part 2; pp. 891-901.

23. Zimmerman, A.R. Abiotic and microbial oxidation of laboratory-produced black carbon (biochar). Environ. Sci. Technol. 2010, 44, 1295-1301. [CrossRef] [PubMed]

24. Krishnakumar, S.; Kumar, S.R.; Mariappan, N.; Surendar, K.K. Biochar-boon to soil health and crop production. Afr. J. Agric. Res. 2013, 8, 4726-4739.

25. Petter, F.A.; Madari, B.E.; Silva, M.A.S.D.; Carneiro, M.A.C.; Carvalho, M.T.D.M.; Marimon Júnior, B.H.; Pacheco, L.P. Soil fertility and upland rice yield after biochar application in the cerrado. Pesqui. Agropecu. Bras. 2012, 47, 699-706. [CrossRef]

26. Zhang, A.; Bian, R.; Pan, G.; Cui, L.; Hussain, Q.; Li, L.; Zheng, J.; Zheng, J.; Zhang, X.; Han, X.; et al. Effects of biochar amendment on soil quality, crop yield and greenhouse gas emission in a chinese rice paddy: A field study of 2 consecutive rice growing cycles. Field Crops Res. 2012, 127, 153-160. [CrossRef]

27. Alling, V.; Hale, S.E.; Martinsen, V.; Mulder, J.; Smebye, A.; Breedveld, G.D.; Cornelissen, G. The role of biochar in retaining nutrients in amended tropical soils. J. Plant Nutr. Soil Sci. 2014, 177, 671-680. [CrossRef]

28. Fernández, F.G.; Hoeft, R.G. Managing soil pH and crop nutrients. Available online: http:/ /extension.cropsciences.illinois.edu/handbook/pdfs/chapter08.pdf (accessed on 16 December 2015).

29. Sohi, S.P.; Krull, E.; Lopez-Capel, E.; Bol, R. A review of biochar and its use and function in soil. Adv. Agron. 2010, 105, 47-82.

30. Havlin, J.L.; Beaton, J.D.; Tisdale, S.L.; Nelson, W.R. Soil Fertility and Fertilizers, an Introduction to Nutrient Management, 6th ed.; Prentice Hall: Upper Saddle River, NJ, USA, 1999.

31. Laird, D.A.; Fleming, P.; Davis, D.D.; Horton, R.; Wang, B.; Karlen, D.L. Impact of biochar amendments on the quality of a typical midwestern agricultural soil. Geoderma 2010, 158, 443-449. [CrossRef]

32. Martinsen, V.; Mulder, J.; Shitumbanuma, V.; Sparrevik, M.; Borresen, T.; Cornelissen, G. Farmer-led maize biochar trials: Effect on crop yield and soil nutrients under conservation farming. J. Plant Nutr. Soil Sci. 2014, 177, 681-695. [CrossRef]

33. Masulili, A.; Utomo, W.H.; Syechfani, M.S. Rice husk biochar for rice based cropping system in acid soil 1. The characteristics of rice husk biochar and its influence on the properties of acid sulfate soils and rice growth in west kalimantan, indonesia. J. Agric. Sci. 2010, 2, 39-47. [CrossRef]

34. De Melo Carvalho, M.T.; de Holanda Nunes Maia, A.; Madari, B.E.; Bastiaans, L.; van Oort, P.A.J.; Heinemann, A.B.; Soler da Silva, M.A.; Petter, F.A.; Marimon, B.H., Jr.; Meinke, H. Biochar increases plant-available water in a sandy loam soil under an aerobic rice crop system. Solid Earth 2014, 5, 939-952. [CrossRef]

35. Kammann, C.I.; Schmidt, H.-P.; Messerschmidt, N.; Linsel, S.; Steffens, D.; Mueller, C.; Koyro, H.-W.; Conte, P.; Stephen, J. Plant growth improvement mediated by nitrate capture in co-composted biochar. Sci. Rep. 2015. [CrossRef]

(C) 2015 by the authors; licensee MDPI, Basel, Switzerland. This article is an open access article distributed under the terms and conditions of the Creative Commons by Attribution (CC-BY) license (http://creativecommons.org/licenses/by/4.0/). 